\title{
JAPOŃSKA PROZA LIRYCZNA NA PRZYKŁADZIE ISE MONOGATARI (OPOWIEŚCI Z ISE)
}

\author{
IWONA KORDZIŃSKA-NAWROCKA ${ }^{1}$ \\ (Uniwersytet Warszawski)
}

\begin{abstract}
Słowa kluczowe: Ise monogatari - Opowieści z Ise - ōchō monogatari - esej dworska Ariwara Narihira - powieść liryczna - mukashi otoko - miyabi - elegancja dworska
\end{abstract}

Key words: Ise monogatari - Tales of Ise - ōchō monogatari - Ariwara Narihira - poem tale mukashi otoko - miyabi - courtly elegance

\begin{abstract}
Abstrakt: Iwona Kordzińska-Nawrocka. JAPOŃSKA PROZA LIRYCZNA NA PRZYKŁADZIE ISE MONOGATARI (OPOWIEŚCI Z ISE). PORÓWNANIA 18, 2016. T. XVIII. S. 115-134. ISSN 1733-165X. Celem badawczym artykułu jest przedstawienie Ise monogatari (Opowieści z Ise) najwybitniejszego dzieła należącego do podgatunku opowieści dworskich zwanego uta monogatari (proza liryczna). Na tle innych typów opowieści dworskich (ōchō monogatari) uta monogatari stanowi niezwykle oryginalną odmianę prozy, w której elementy fabularne pełnią rolę drugorzędną, a świat przedstawiony jest kreowany przede wszystkim poprzez poetyckie przetworzenia realiów życia. Ogniwem łączącym w tym utworze poszczególne eseje poetyckie w jedną całość jest postać mukashi otoko, "mężczyzny z dawnych czasów”, pod którą ukrywa się Ariwara Narihira (825-880), poeta i dworzanin. Niniejszy artykuł przedstawia główne wyróżniki gatunkowe, jak również uwarunkowania światopoglądowe i społeczne, które sprawiły, że utwór ten utożsamiany jest z estetyką dworskiej elegancji miyabi.
\end{abstract}

Abstract: Iwona Kordzińska-Nawrocka. JAPANESE LYRICAL PROSE ON THE EXAMPLE OF ISE MONOGATARI (TALES FROM ISE). COMPARISONS 18, 2016. Vol. XVIII. P. 115-134. ISSN 1733-165X. The aim of this article is to introduce Ise monogatari (Tales of Ise) - the most outstanding example of the court tales genre called uta monogatari (lyrical prose). Amongst court tales (óchō monogatari), uta monogatari proves to be an extremely original type of prose, in which the storyline plays a secondary role while the world described is mostly depicted through the poetic

${ }^{1}$ E-mail Address: i.nawrocka@uw.edu.pl 
re-creation of reality. The element that links all the episodes of Ise monogatari into a whole is the figure of mukashi otoko, "a Man of Old", implying Ariwara Narihira (825-880), a poet and nobleman. The article presents the main characteristics of the genre, the worldview and social background, the reasons for which this literary work is identified with the beauty of courtly elegance, miyabi.

Ise monogatari (Opowieści z Ise) jest najwybitniejszym przykładem podgatunku opowieści dworskich zwanego uta monogatari, czyli proza liryczna. Uta monogatari wyróżnia się, na tle innych typów opowieści dworskich (ōchō monogatari) ${ }^{2}$, niezwykle oryginalną konstrukcją, w której elementy fabularne pełnią rolę drugorzędną, a świat przedstawiony jest kreowany przede wszystkim poprzez poetyckie przetworzenia realiów życia. Ogniwem łączącym w tym utworze poszczególne eseje poetyckie w jedną całość jest postać mukashi otoko, „mężczyzny z dawnych czasów", pod którą ukrywa się Ariwara Narihira (825-880), poeta i dworzanin.

W niniejszym tekście zostaną przedstawione najważniejsze wyróżniki gatunkowe Ise monogatari, a także uwarunkowania światopoglądowe i społeczne, które sprawiły, że utwór ten utożsamiany jest z pięknem dworskiej elegancji miyabi.

\section{Ise monogatari jako tekst kultury dworskiej}

Ise monogatari jest jednym $\mathrm{z}$ najbardziej znanych utworów okresu Heian (794-1185/1192), podczas którego wykształciła się niezwykle wyrafinowana i wysoko rozwinięta kultura dworska. Jej atrybutami wyróżniającymi był szczególny stosunek ówczesnych Japończyków do piękna w ogóle, a przede wszystkim do piękna przyrody i przemian czterech pór roku, jak również wszechobecna estetyzacja życia codziennego. Arystokraci, którzy każdy aspekt czy przejaw codziennej aktywności potrafili zamienić $\mathrm{w}$ artystyczne działanie, stworzyli różnorodne formy sztuki, jak na przykład sztuka epistolarna, kaligrafia, poezja, malarstwo, moda i stroje czy sztuka tworzenia zapachów. Estetyczne podejście do życia i daleko posunięta wrażliwość (aware) na piękno otaczającego świata były wyróżnikami

${ }^{2}$ Opowieści dworskie tworzą następujące podgatunki: opowieści fikcyjne (tsukuri monogatari), np. Taketori monogatari (Opowieść o zbieraczu bambusów, X w.), Genji monogatari (Opowieść o księciu Genjim, 1008), opowieści historyczne (rekishi monogatari), np. Eiga monogatari (Opowieść o rozkwicie, XI w.), opowieści anegdotyczne (setsuwa monogatari), np. Konjaku monogatari (Opowieści dawne i dzisiejsze, XII w.), opowieści nowelistyczne (tanpen monogatari), np. Tsutsumi Chünagon monogatari (Opowieści Radcy Tsutsumi, XI-XII w.). 
wyłącznie szlachetnie urodzonych (yoki hito), a więc przedstawicieli dworu cesarskiego i arystokratów.

Ise monogatari jako tekst kultury pokazuje nie tylko ówczesne obyczaje i różnorodne artystyczno-estetyczne formy życia codziennego, jest ponadto biograficznym rejestrem życia emocjonalnego wysoko postawionego arystokraty, którego poematy stanowią główną oś konstrukcyjną utworu. Od momentu powstania dzieło cieszy się dużą popularnością, było i nadal jest w Japonii powszechnie znane oraz czytane, doczekało się również wielu opracowań naukowych dotyczących między innymi: struktury i elementów konstrukcji ${ }^{3}$, tematyki, wątków i motywów literackich oraz języka poetyckiego i narracyjnego ${ }^{4}$, a także aspektów światopoglądowych ${ }^{5}$. W Polsce nie ukazał się niestety ani pełny przekład Ise monogatari, ani żadne opracowanie przybliżające sam utwór należący do niezwykle oryginalnego gatunku będącego połączeniem liryki osobistej i prozy narracyjnej, wyprzedzającym o kilka stuleci europejską prozę poetycką doby romantyzmu. Tekst ten należy traktować w szerszym kontekście kulturowym jako odzwierciedlenie rzeczywistości pokazanej poprzez filtr uczuć i emocjonalnych doświadczeń bohatera.

Zarówno tytuł, jak i autor dzieła wciąż pozostają kwestią niewyjaśnioną. W innych utworach okresu Heian pojawiają się wprawdzie odniesienia do Ise monogatari, ale różne nazwy, pod jakimi to dzieło występuje, utrudniają zrozumienie znaczenia samego tytułu. Na przykład w Genji monogatari (Opowieść o księciu Genjim, 1008), w księdze Agemaki (Dziewczęca fryzura) utwór jest nazywany Zaigo ga monogatari, czyli Esej o Zaigo (Murasaki Shikibu t. 13-234), zaś w księdze Eawase (Turniej malarski) (Murasaki Shikibu t. 14-371) po prostu Ise monogatari. Warto dodać, że pseudonim Zaigo zaledwie w pośredni sposób wskazuje na Ariwarę, ponieważ oba nazwiska zapisuje się dwoma znakami, z których pierwszy ma taką samą formę graficzną, ale może być odczytywany w dwojaki sposób: zai lub ari. Drugi znak natomiast oznacza liczbę pięć, i wskazuje na fakt, że był on piątym synem księcia Abo.

Z kolei w Sagoromo monogatari (Opowieść o Sagoromo, XII w.) zamiast Ise monogatari pojawia się tytuł Zaigo chūshō no nikki, czyli Pamiętnik oficera Zaigo, co jest

${ }^{3}$ M.in. prace: Ikedy Kikan, Ise monogatari ni tsuite no kenkyū (Badania na temat Ise monogatari), Katagiri Yōichi, Ise monogatrai no kenkyū, kenkyūhen (Badania na temat Opowieści z Ise, tom studiów) oraz Yamady Seiichi, Ise monogatari no seiritsu to denpon no kenkyū (Badania na temat powstania i wersji odpisów Opowieści z Ise).

${ }^{4}$ M.in. prace: Hary Kunito, Ise monogatari no genpükei ai no yukue tazunete (Pierwotny krajobraz Opowieści z Ise, w poszukiwaniu miłości) i Ise monogatari bungeishiteki kenkyū (Studia na temat badań literackich nad Opowieściami z Ise).

${ }^{5}$ Prace badaczy-obcokrajowców, m.in.: Edwin A. Cranston, The Dark Path: Images of Longing in Japanese Love Poetry, Michele Marra, A Lesson the Leaders: Ise monogatari and the code of miyabi, Richard Bowring, The Ise monogatari: A Short Cultural History; Joshua S. Mostow, Modern Construction of Tales of Ise: Gender and Courtliness. 
ewidentnym nawiązaniem do tego, że Ariwara na pewnym etapie swojej zawodowej kariery uzyskał stopień chūshō - kapitana (Sagoromo monogatari 52).

Istnieje również kilka teorii dotyczących znaczenia tytułu utworu. Zgodnie z pierwszą z nich autorstwo dzieła przypisuje się znanej poetce Ise (?-939), stąd $\mathrm{w}$ tytule pojawia się jej pseudonim. Poetka, wywodząca się $\mathrm{z}$ rodu Fujiwara, została nazwana $\mathrm{w}$ ten sposób prawdopodobnie dlatego, że jej ojciec Tsugukage pełnił funkcję gubernatora prowincji Ise. Druga teoria odnosi się do sześćdziesiątego dziewiątego eseju, w którym przedstawiona jest historia romansu Ariwary z kapłanką świątyni Ise ${ }^{6}$. Dla wielu badaczy jest to najważniejsza część tematyczna utworu.

Również autor dzieła wciąż pozostaje nieznany. Najwcześniejsza teoria, rozpowszechniona już w okresie Muromachi (1392-1573) przez Sanjō Kanetokiego (daty życia nieznane), przypisuje autorstwo Ariwarze. Współcześnie jednak wyklucza się możliwość napisania dzieła przez samego poetę. W okresie Heian nie było bowiem zwyczaju tworzenia przez twórców ich prywatnych autobiografii lub osobistych antologii poetyckich, z reguły dopiero po śmierci danego autora rodzina lub przyjaciele wybierali najwybitniejsze wiersze i wydawali w postaci imiennego zbioru.

Najwięcej zwolenników ma teoria przypisująca stworzenie dzieła poetce Ise. O jej słuszności świadczą liczne podobieństwa związane ze stylem pisarskim, a także samym tytułem utworu, który nawiązuje do imienia poetki.

Z kolei w okresie Edo (1603-1868) badacze tzw. szkoły narodowej (kokugaku), tacy, jak Kamo Mabuchi (1697-1769) i Motoori Norinaga (1730-1801) uważali, że Ise monogatari zostało napisane prawdopodobnie przez osobę pozostającą $\mathrm{w}$ bliskich, a więc rodzinnych lub przyjacielskich relacjach z rodem Ariwary. Jako potencjalnych twórców wymieniali między innymi: brata Ariwary - Ariwarę Yukihirę ${ }^{7}$ (808-893), Ki no Tsurayukiego (868-945) ${ }^{8}$ oraz Minamoto Shitagō (911-983)9.

Niestety do naszych czasów nie zachował się oryginał Ise monogatari, a utwór przetrwał w kilku różnych odpisach. Najbardziej znana jest wersja pióra Fujiwary Teiki (1162-1241) zwana Teikabon (księga Teiki) i licząca 125 opowieści. Teikabon, przepisana w okresie Muromachi przez Sanjōnishi Sanetakę (1455-1537), przechowywana jest obecnie w bibliotece Uniwersytetu Gakushūin (Gakushūin daigaku)

${ }^{6}$ Świątynia Ise (Ise Jingū) - chram sintoistyczny znajdujący się w mieście Ise, prefekturze Mie. Poświęcony jest najważniejszemu bóstwu w panteonie sintoistycznym - bogini słońca Amaterasu.

7 Ariwara Yukihira (818-893), brat Ariwary, dworzanin i poeta. Był drugim dzieckiem księcia Abe.

${ }^{8}$ Ki no Tsurayuki (868-945), jeden z najwybitniejszych poetów okresu Heian, kompilator antologii Kokin wakashū (Zbiór pieśni dawnych i dzisiejszych, 905), autor słynnego wstępu do tej antologii Kanajo (Wprowadzenie) oraz pamiętnika Tosa nikki (Pamiętnik z Tosy, $\mathrm{X}$ w.).

${ }_{9}$ Minamoto Shitagō (911-983), poeta i pisarz okresu Heian, zaliczany do grona Trzydziestu Sześciu Mistrzów Poezji (Sanjū rokkasen). 
w Tokio. Na tej właśnie wersji oparte zostały wydania Ise monogatari wydawnictw Shōgakukan, Iwanami i Shinchōsha. Bliskie pod względem liczby esejów i układu tematycznego są inne stare manuskrypty (kohon), między innymi Tokiyoribon (Księga Tokiyori, XI w.) i Saifukujibon (Księga świątyni Saifuku, XI w.), wersja przechowywana w świątyni Saifuku. Większą liczbę opowieści zawierają tzw. kōhon, czyli wersje rozszerzone, do których należą Senshūbon (Księga Senshū/Izumo, 136 opowieści) czy Awano kuni bunkobon (Seria z prowincji Awano10, 134 opowieści). Istnieją też wersje krótsze (ryakuhon), a mianowicie Nurigomebon (Księga Nurigome) składająca się z 115 opowieści i Ōshimabon (Księga Ōshima) z 123 opowieści. W niniejszej pracy, jako podstawowe źródło wykorzystana została wersja Teikabon wydawnictwa Shōgakukan.

\section{Cechy dystynktywne utworu}

Nazwa uta monogatari na oznaczenie gatunku będącego połączeniem prozy i liryki, pojawiła się w okresie Meiji (1868-1912). Jako gatunek synkretyczny uta monogatari może przybierać różne formy. Niekiedy zawiera więcej elementów lirycznych, jak na przykład w Ise monogatari, a czasem przeważają partie epickie, jak chociażby w Yamato monogatari (Opowieści z Yamato, 951) czy Heijü monogatari (Opowieść o Heijū, 960-965).

Elementy epickie $\mathrm{w}$ utworach typu uta monogatari to przede wszystkim warstwa fabularna, która jest dość uboga w zdarzenia, ale wyróżnia się w przypadku Ise monogatari pewnym uporządkowaniem chronologicznym, przyjmującym formę opisów poszczególnych etapów w życiu bohatera. Styl narracji jest skromny i ograniczony, a ukazane wydarzenia, które wszechwiedzący narrator dobrze zna z własnego doświadczenia lub opowieści innych, dotyczą przeszłości.

Ważnym elementem świata przedstawionego jest idealizacja życia w stolicy Heian (dzisiejsze Kioto), która staje się miejscem wręcz idyllicznym, krainą szczęścia i elegancji dworskiej miyabi. Stolicy przeciwstawiona jest prowincja (hina), najczęściej miejsce zesłania lub ucieczki bohatera przed przeciwnikami politycznymi, pozbawiona dworskiego ceremoniału i oprawy.

Świat przedstawiony w Ise monogatari jest pełen barw, dźwięków i zapachów związanych z emocjami i szczególną wrażliwością bohatera. Warstwa liryczna $\mathrm{w}$ tym utworze zajmuje dominująca pozycję wobec partii epickich, które stanowią rodzaj prozy sytuacyjnej będącej wyjaśnieniem niekiedy krótkim i prostym, a niekiedy zaś dosyć treściwym okoliczności powstania wiersza przywoływanego $\mathrm{w}$ utworze. Możemy odnaleźć tutaj powiązania z formą oralną zwaną utagatari

\footnotetext{
${ }^{10}$ Awanokuni bunko - seria wydawnicza należąca do rodu Hachisuka, zarządzającego dominium Tokushima w latach 1558-1638.
} 
(opowieści o wierszach), niezwykle popularnej rozrywki wśród ówczesnej arystokracji dworskiej. Wyjaśnienia dotyczące sytuacji powstania danego poematu czy osób uczestniczących w procesie tworzenia były często niezbędne, aby móc w pełni zrozumieć jego znaczenie.

W uta monogatari to właśnie na uta, czyli wierszach koncentruje się uwaga zarówno narratora, jak i czytelnika. Forma wersyfikacyjna partii lirycznych wyróżnia się przede wszystkim charakterystycznym rytmem, wiersze należą bowiem do gatunku poezji sylabicznej względnej, a mianowicie składają się z 5 wersów o układzie 5-7 / 5-7-7 fraz sylabicznych. W japońskiej terminologii literackiej taka forma wiersza nazywana jest tanka, czyli wierszem krótkim.

Wszechobecność poezji w Ise monogatari nie jest rzeczą sztuczną, stworzoną jedynie na potrzeby tego konkretnego utworu czy całego podgatunku literackiego. W ówczesnym społeczeństwie dworskim poezja pełniła bowiem funkcje praktyczne: emotywną - wyrażającą uczucia oraz społeczną - określającą relacje międzyludzkie, pozycję i status uczestników komunikacji interpersonalnej. Poezja zastąpiła zatem inne formy kontaktów międzyludzkich, takich jak na przykład rozmowa, komunikacja niewerbalna, stając się najważniejszym nośnikiem informacji.

W Ise monogatari, jak podkreśla Kuboki Tetsuo, zamieszczone zostały przede wszystkim wiersze osobiste, prywatne nazywane ke no uta (wiersze codzienne), niewiele jest natomiast hare no uta, czyli wierszy odświętnych komponowanych na specjalne okazje, typu urodziny czy turnieje poetyckie (Kuboki 32). Wiersz odświętny charakteryzował się określoną zawartością tematyczną spełniającą kryteria przedstawione $\mathrm{w}$ nadanym mu tytule (daiei), a dotyczył najczęściej spraw ogólnych i przeznaczony był do słuchania przed szerszą publicznością. Poezja prywatna natomiast, skierowana do jednego lub grupy konkretnych odbiorców (rodzina, przyjaciele, towarzysze podróży), z reguły nie była opatrzona tytułem. Kuboki rozróżnia dwie jej odmiany, a mianowicie zōtōka (dosł. pytania i odpowiedzi) - rodzaj wiersza będącego formą korespondencji pomiędzy dwiema zaangażowanymi najczęściej uczuciowo osobami, i mającego charakter liryki inwokacyjnej oraz dokueika, czyli monolog liryczny, w którym podmiot liryczny pośrednio lub bezpośrednio dokonuje aktu wyznania (Kuboki 34-35). Obie formy poetyckie odzwierciedlają szczególną wrażliwość ówczesnych arystokratów na otaczający ich świat piękna i emocjonalnych wzruszeń, stając się jednocześnie głównym sposobem jego wyrażania. W społeczeństwie dworskim poezja, co należy szczególnie podkreślić, była tworzona w sposób spontaniczny, naturalny, pod wpływem różnorodnych bodźców zewnętrznych. Ekspresyjną rolę poezji w życiu codziennym arystokratów potwierdzają dwa synonimiczne Wprowadzenia (Kanajo i Manajo) do antologii cesarskiej Kokinwakashū (Zbiór pieśni dawnych i dzisiejszych, 905), stanowiące jednocześnie pierwszą próbę sformułowania poetyki normatywnej w historii literatury japońskiej. Autorem pierwszego wprowadzenia Kanajo, napi- 
sanego po japońsku jest Ki no Tsurayuki, a drugiego Manajo napisanego w języku chińskim jest Ki no Yoshimochi (?-919).

Ki no Tsurayuki w Kanajo w następujący sposób wyjaśnia naturalność uczucia, jakim jest pragnienie tworzenia poezji:

Pieśń japońska [yamato uta] wyrasta z serc ludzkich i rozkwita w postaci wielu liści słów. Ludzie żyjący na tym świecie, mają dużo różnych doświadczeń, dlatego to, co myślą, widzą i słyszą wyrażają w postaci pieśni. (Kokinwakashū 7)

Podobnie analizuje proces twórczy Ki no Yoshimochi w Manajo:

Korzenie pieśni japońskiej [waka] można odnaleźć w ludzkich sercach, które rozkwitają w postaci lasu słów. Żyjący na tym świecie ludzie nie mogą pozostać bezczynni. Poddają się myślom i dążeniom i na zmianę odczuwają radość i smutek. Dążenia rodzą emocje, a ich odzwierciedleniem są pieśni w postaci słów. (Kokinwakashū 259.

Jak wynika z powyższych cytatów, człowiek, który rodzi się zupełnie niemy i początkowo pozostaje nieaktywny, stopniowo pod wpływem różnorodnych bodźców zewnętrznych zaczyna działać, myśleć i odczuwać, co z kolei przeradza się w naturalną potrzebę wyrażenia swoich uczuć i myśli w formie lirycznej. Różnorodne czynniki zewnętrzne, które pobudzają człowieka do twórczej aktywności, to przede wszystkim piękno przyrody i przemiany czterech pór roku, uczucie miłości, radości, smutku i różnorodne doświadczenia życia codziennego. Watanabe Hideo określa to mianem teorii emotywno-sensualnej (seijōron), podkreślając, że w oczach starożytnych Japończyków człowiek wrażliwy powinien był wypowiadać się za pomocą języka poezji, który należał do najlepszych sposobów wyrażenia samego siebie (Watanabe 14).

\section{Konstrukcja głównego bohatera}

Badacze ((Fukui 113-128, Kobayashi 122) są zgodni, że Ise monogatari nie jest pod względem tematycznym jednolitą całością, ponieważ składa się z kilku cykli opowieści. Dominującym wątkiem tematycznym jest historia życia uczuciowego „pewnego mężczyzny”, którym w większości przypadków jest Ariwara, choć możemy znaleźć również eseje z innymi postaciami w roli głównej.

Każda historia rozpoczyna się w określony sposób, a mianowicie utartym zwrotem "dawno temu pewien mężczyzna" (mukashi otoko), "dawno temu” (mukashi) lub „był sobie dawno temu pewien mężczyzna” (mukashi otoko arikeri). W niektórych esejach podane są nazwiska konkretnych osób najczęściej związanych z głównym bohaterem więzami rodzinnymi lub relacjami miłosnymi, względnie przyjaźnią. 
Ariwara jako postać pierwszoplanowa w utworze, wykreowany został z jednej strony na ideał męskości, wzorzec elegancji dworskiej (miyabi) i wrażliwości (aware), $\mathrm{z}$ drugiej zaś jako bohater w pewnym stopniu tragiczny, pozbawiony możliwości awansu i odcięty od spektakularnej kariery dworskiej, jaką powinien zrobić zgodnie ze swoim wysokim pochodzeniem. Był bowiem dzieckiem pary wywodzącej się z rodu cesarskiego. Jego ojciec, książę Abo, był synem cesarza Heizei’a (774-824, panował 806-809), matka zaś, księżniczka Ito - córką cesarza Kammu (737-806, panował 781-806). W 826 roku wraz z bratem Yukihirą otrzymał nazwisko rodowe Ariwara i został wykreślony z rejestrów rodu cesarskiego, co całkowicie zamknęło mu drogę do tronu i skazało na powolną wspinaczkę po szczeblach dworskiej kariery. W rezultacie udało mu się zdobyć jedynie czwartą rangę dworską i zaszczytny tytuł szambelana (kurōdo no tō, 879 rok). W kronice Sandai jitsuroku (Zapiski trzech pokoleń, 901) można odnaleźć krótką wzmiankę na jego temat:

Ariwara był wyjątkowo przystojny, ale nie potrafił okiełznać swoich namiętności. Brakowało mu wprawdzie wykształcenia w dziedzinie klasyki chińskiej, świetnie natomiast komponował poezję japońską [waka]. (Waka no kaishaku to kanshō jiten 188)

Przedstawiony powyżej portret Ariwary jest dosyć ogólnikowy, brak jest tutaj jakichkolwiek szczegółów dotyczących jego pochodzenia czy faktów z życia. Jest to raczej wyraz krytyki, uwzględniającej jednak pewne zalety i atuty poety, takie jak atrakcyjna powierzchowność oraz zdolności poetyckie.

W podobny sposób ocenia Ariwarę w Kanajo Tsurayuki, dostrzegając pewne niedostatki w jego wykształceniu.

Ariwara jest niezwykle uczuciowy, ale brak mu umiejętności odpowiedniego wyrażania nagromadzonych w nim emocji. Przypomina zwiędnięty kwiat, którego kolor już dawno zblakł, ale zapach wciąż pozostał. ((Kokinwakashū 9)

Pozycja Ariwary jako wybitnego poety, twórcy przede wszystkim romantycznej poezji miłosnej, została jednak potwierdzona przez zaliczenie go do grona Sześciu Mistrzów Poezji (Rokkasen) ${ }^{11}$.

Sam utwór Ise monogatari traktowany jest jako manifestacja piękna miyabi, czyli dworskiej elegancji i wytworności, a występujący w nim Ariwara staje się ucieleśnieniem miyabio - mężczyzny kierującego się w życiu potrzebą bycia eleganckim i wytwornym. Słowo miyabi należy do kluczowych pojęć w tradycyjnej japońskiej estetyce i literaturze. Wywodzi się od czasownika miyabu, który powstał z połą-

${ }^{11}$ Sześciu Mistrzów Poezji - grono najwybitniejszych twórców reprezentujących wyrafinowany świat kultury dworskiej. Oprócz Ariwary znaleźli się w nim również: Ono Komachi (IX w. dokładne daty życia nieznane), mnich Henjō (816-890), Ōtomo Kuronuchi (IX w. dokładne daty życia nieznane), Bun'ya Yasuhide (IX w. dokładne daty życia nieznane) oraz mnich Kisen (810-824). 
czenia sufiksu bu oznaczającego: „być taki jak”, ,być tego typu jak”, „być niczym”, z rzeczownikiem miya - "świątynia”, "dwór cesarski”, "pałac cesarski" (Nihongo gogen jiten). Powstały w ten sposób czasownik wskazywał zatem na wszystko to, co było związane $\mathrm{z}$ cesarzem, dworem i życiem dworzan w ówczesnej stolicy Heian. Dwór stał się synonimem życia eleganckiego i wyrafinowanego, a zatem jedynego, które było godne naśladowania.

W Ise monogatari piękno miyabi pojawia się najczęściej w kontekście opisu głównego bohatera, który w każdej sytuacji zachowuje się niezwykle elegancko. Już pierwsza esej, w której Ariwara wyrusza w podróż zaraz po ceremonii dojrzałości i zakochuje się w dwóch pięknych siostrach mieszkających w wiosce Kasuga, pokazuje jego wrażliwość i wyrafinowaną elegancję. Stojąc za ogrodzeniem domu, w którym mieszkają młode kobiety, Ariwara obserwuje je z oddali i głęboko poruszony ich pięknem, odcina skrawek swojej szaty i wypisuje na niej poemat. Takie zachowanie narrator określa właśnie mianem miyabi:

Mukashibito wa kaku ichi hayaki miyabi o namu shikeru.

Dawniej ludzie zachowywali się niezwykle elegancko. (Ise monogatari 134)

Narrator dość konsekwentnie odtwarza życie uczuciowe bohatera, zaczynając od jego pierwszej przygody miłosnej, a kończąc na wierszu pożegnalnym poety skomponowanym tuż przed jego śmiercią. Ostatni, sto dwudziesty piąty esej przyjmuje kształt lirycznego testamentu poety.

Dawno temu pewien mężczyzna ciężko zachorował i był bliski śmierci. Napisał więc swój ostatni poemat:

Tsui ni yuku michi to ha kanete kikishikado kinō kyō to wa omowazarishi o.

Ostatnia droga, którą każdy z nas podaża. Styszatem o niej już dawno, ale nie wiedziatem, że przyjdzie mi kroczyć nia już dziś. (Ise monogatari 234)

Między pierwszą a ostatnią opowieścią pojawia się wiele różnorodnych historii miłosnych oraz przygód, które tworzą jednak pewną logicznie i chronologicznie uporządkowaną całość. Można wyraźnie wyróżnić określone cykle tematyczne rozwijające i pogłębiające konkretny wątek miłosny bądź przygodowy, z których najważniejsze i najciekawsze są trzy, a mianowicie opowieść o cesarzowej Nijō, opowieść o wyprawie do prowincji wschodnich oraz opowieśc o kapłance Ise.

\section{Opowieść o cesarzowej Nijō}

Opowieść o cesarzowej Nijō, czyli Nijō kisaki monogatari jest historią romansu Ariwary z Fujiwarą Takaiko, przyszłą cesarzową Nijō (842-910), żoną cesarza Seiwy (850-880, panował 858-876) i matką następcy tronu cesarza Yōzei’a (868-949, 
panował 876-884). Ich związkowi poświęcone zostało kilka esejów, między innymi trzeci, czwarty, piąty, szósty oraz sześćdziesiąty piąty i siedemdziesiąty szósty. Namiętne uczucie łączące bohatera z córką Fujiwary Nagaru (802-856) jest przykładem związku zakazanego, który nie znalazł aprobaty w rodzinie przyszłej cesarzowej, rozwijał się zatem w całkowitej tajemnicy. Do romansu wprowadza esej trzeci, w którym Ariwara wysyła do ukochanej list i dołącza do niego suszone wodorosty (hijiki), które wówczas uważane były za przysmak i towar luksusowy. List zawierał następujący poemat:

Omoi araba mugura no yado ni ne mo shinamu hijiki mono ni wa sode o shitsutsu.

Pragnę spędzić $z$ Toba noc. Ukryjmy się w starym domu, a rękawy naszych szat postuża nam za postanie. O ile tylko mnie kochasz. (Ise monogatari 135)

Na uwagę zasługuje tutaj słowo hijiki mono - poetycki homonim (kakekotoba) ${ }^{12}$ o podwójnym znaczeniu. Po pierwsze wskazuje na dołączone do listu wodorosty, prezent od Ariwary, po drugie zaś symbolizuje hishiki mono, czyli nocne posłanie, a zatem stanowi zaproszenie do spędzenia razem nocy. W partii epickiej wyjaśniono, że Fujiwara Takaiko nie była jeszcze wówczas cesarzową.

Do powyższej historii nawiązuje esej sto sześćdziesiąty pierwszy $\mathrm{z}$ innego dzieła z gatunku uta monogatari, a mianowicie Yamato monogatari, w którym możemy znaleźć objaśnienie, iż Ariwara oświadczył się księżnej, przesyłając jej list i wodorosty hijiki (Yamato monogatari 411).

Yamato monogatari opisuje historię ich romansu, pokazując kochanków kilkanaście lat później, kiedy spotykają się podczas pielgrzymki cesarzowej Nijō do świątyni Ōharano. Ariwara wraz z innymi dworzanami towarzyszy cesarzowej, przy samej świątyni staje $\mathrm{w}$ cieniu za jej powozem i bardzo cicho, tak, aby nikt poza nią nie mógł go usłyszeć, recytuje wiersz:

Ōhara ya Oshio no yama mo kyō koso wa kamiyo no koto o omoiizurame.

Góry Oshio i wzgórza Ōhara. Chyba właśnie dzisiaj z nostalgia wspominaja odległe czasy bóstw. (Yamato monogatari 411)

Należy wyjaśnić tutaj znaczenie metafory kamiyo no koto (dosł. czasy bóstw). Otóż Ariwara z jednej strony nawiązuje do bóstwa, które jest związane ze świątynią Ōharano ${ }^{13}$, a jednocześnie wskazuje na cesarzową, wychwalając jej postać i pisząc wiersz upamiętniający jej pielgrzymkę. Z drugiej strony metafora ta staje

${ }^{12}$ Kakekotoba, czyli homonim należy do najpopularniejszych tropów poetyckich używanych w poezji starojapońskiej. Słowa o dwóch znaczeniach wykorzystywane były do uzyskania dodatkowego pola semantycznego.

${ }^{13} \mathrm{~W}$ świątyni Ōharano czczone jest bóstwo Ame no Koyane no mikoto uważane za protoplastę rodu Fujiwara. 
się symbolem stałości i nieprzemijalności wielkiego uczucia, jakim darzy Ariwara cesarzową. Uczucie to pomimo wielu przeszkód wciąż pozostaje niezwykle silne. Cesarzowa wzruszona postawą poety określa ją mianem okashi, czyli czarującej.

W czwartym eseju Ise monogatari miłość i związek łączący Ariwarę i Takaiko wychodzą na jaw. Takaiko, która wówczas zamieszkiwała rezydencję w Piątej Alei (Gojō) należącą do Junko, żony cesarza Ninmyō (810-850, panował 833-850), nagle znika i nikt nie chce udzielić Ariwarze informacji, gdzie obecnie przebywa. Zrozpaczony Ariwara udaje się do opuszczonego domu przy Piątej Alei, gdzie wcześniej się spotykali, i z nostalgią wspomina ukochaną:

Następnej wiosny, kiedy kwiaty śliwy były w pełnym rozkwicie, mężczyzna przyszedł tęskniąc za zeszłym rokiem. Stanął i popatrzył, a następnie usiadł i ponownie się rozejrzał, uświadamiając sobie, że nic nie przypomina mu już dawnych czasów. Zapłakał gorzko siedząc na werandzie pustego domu. Następnie położył się i patrząc na zachodzący księżyc wyrecytował poemat o swoich uczuciach:

Tsuki ya aranu haru ya mukashi naranu wagami hitotsu wam oto no mi ni shite.

Czy to księżyc czy może i wiosna nie sa już takie jak dawniej?

Nie, to tylko ja się nie zmienitem. (Ise monogatari 136)

Cesarzowa Junko, ciotka Takaiko, wzruszona zachowaniem Ariwary pozwala ponownie spotykać się zakochanym, czemu jest poświęcony kolejny, piąty esej. Takaiko wraca do pałacu przy Piątej Alei, a mężczyzna zaczyna ją odwiedzać w tajemnicy. Jednak ojciec kobiety wkrótce dowiaduje się o wszystkim i ustawia straż przed domem, w którym przybywa jego córka. Ariwara nie mogąc dotrzeć do ukochanej wysyła jej wiersz:

Hito shirenu waga kayoiji no sekimori wa yoi yoi goto ni uchi mo nenanamu.

Dotąd nikomu nieznana ścieżka, która potajemnie pokonywatem.

Teraz jest pilne strzeżona, a ja chciatbym, aby strażicy zapadali w sen każdej nocy. (Ise monogatari 137)

Kolejna historia $\mathrm{z}$ ich trudnego związku przedstawiona została $\mathrm{w}$ eseju szóstym.

Dawno temu był sobie mężczyzna. Przez wiele lat próbował zdobyć pewną niedostępną damę. Wreszcie porwał ją i razem uciekli pod osłoną nocy. Nad ranem przybyli nad rzekę Akutagawa. Kobieta patrząc na rosę pokrywającą trawy, zapytała go, co tak błyszczy.

Kochankowie mieli jeszcze przed sobą długą drogę, kiedy zastała ich kolejna noc. Nie wiedzieli, że zatrzymali się $\mathrm{w}$ niebezpiecznym miejscu zamieszkiwanym przez demony. Nagle zaczął padać silny deszcz i waliły pioruny. Mężczyzna umieścił kobietę w starej i zniszczonej przydrożnej szopie, a sam trzymał straż na zewnątrz. W pogotowiu miał łuk i strzały. Pragnął, aby noc skończyła się jak najszybciej. 
W czasie, kiedy mężczyzna nieświadomy niebezpieczeństwa pilnował wejścia, przyszły demony i w mgnieniu oka pożarły jego ukochaną. Kobieta wołała wprawdzie o pomoc, ale mężczyzna nie słyszał jej ogłuszony hukiem błyskawic i piorunów. Powoli zaczęło świtać. Mężczyzna zajrzał do środka i zobaczył, że jego ukochana zniknęła. Zalewając się łzami rozpaczy, ledwo trzymał się na nogach. Znikąd jednak nie widział ratunku.

Shiratama ka nani zo to hito no toishi toki tsuyu to kotaete kienamashi mono o.

Kiedy zapytałaś, co tak lśni w trawie, odpowiedziałem - to rosa. A może to byty perty.

Chciałbym zniknać wraz z Tobą. (Ise monogatari 137-138)

Ariwara, nie mogąc spotykać się z ukochaną, decyduje się na niebezpieczny i ryzykowny krok, a mianowicie porwanie kobiety. Jednak w pogoń za zbiegami wyruszają jej dwaj bracia Mototsune (836-891) i Kunitsune (daty życia nieznane). To właśnie oni przedstawieni są jako straszliwe demony (oni) pożerające kobietę. Porwanie nie udaje się, a Ariwara świadomy naganności swoich uczuć próbuje oddać się pokucie.

W eseju sześćdziesiątym piątym Takaiko przebywa już na dworze i służy Junko, cesarzowej matce. Potajemnie spotyka się w swoich komnatach z Ariwarą. Kobieta doskonale wie, że dopuszcza się przestępstwa, tłumacząc sobie, iż: „jest to dla mnie bardzo przykre i trudne, ale pewnie razem zginiemy. Nie wolno nam robić takich rzeczy." (Ise monogatari 186). Wówczas mężczyzna przesyła jej poemat:

Omou ni wa shinoburu koto zo makenikeru au ni shikaeba sa mo araba are.

Miłość mnie pokonała. Jeśli tylko możemy się spotkać,

to jest mi wszystko jedno, co się z nami stanie. (Ise monogatari 176)

Ariwara gotów jest całkowicie zatracić się w uczuciu, niestety zostaje przez służbę zauważony, kiedy wchodzi do komnat Takaiko. Pozostają mu już tylko modły do bóstw, aby móc się odkochać.

Mężczyzna gorąco modlił się do Buddy i bóstw. Lecz jego uczucie tylko się wzmocniło i płonął miłością jeszcze większą niż przedtem. Wówczas wezwał kapłanów sintoistycznych i innych egzorcystów, którzy przygotowali specjalne rytualne przedmioty do przeprowadzenie ceremonii oczyszczenia z występnej miłości. Im bardziej angażowali się w rytuały oczyszczenia, tym bardziej cierpiał z powodu miłości. (Ise monogatari 187)

W końcu cesarz dowiaduje się o romansie i skazuje Ariwarę na wygnanie do prowincji wschodnich.

Opowieśc o cesarzowej Nijō ma wymiar nie tylko romantyczny, ale również polityczny. Łączące ich uczucie rozgrywa się w cieniu ostrej walki o władzę i wpływy na dworze pomiędzy rodem Fujiwara a Ariwarą i jego rodziną. Ariwara niestety przegrywa walkę i musi opuścić stolicę. 


\section{Opowieść o podróży do wschodnich prowincji}

Wygnanie ze stolicy i zesłanie do prowincji wschodnich, czyli opowieść o podróży do wschodnich prowincji (Azumakudari monogatari) rozpoczyna drugi cykl tematyczny związany z życiem Ariwary. Składa się na niego kilka esejów, między innymi: esej od siódmego do piętnastego, a następnie sto piętnasty, sto szesnasty i sto czterdzieści trzeci.

Temat wygnania ze stolicy, który Orikuchi Shinobu nazwał toposem „zesłania bohatera szlachetnie urodzonego" (kishu ryüritan), należał do niezwykle popularnych w literaturze dworskiej (Kuniaki 34-35). Można odnaleźć pewne stałe elementy, które go konstytuują. Są to między innymi:

1. wysokie pochodzenie głównego bohatera, którego często już same narodziny odbywają się w atmosferze skandalu;

2. dopuszczenie się przez bohatera czynów, które są niezgodne z prawem bądź z powszechnie przyjętymi normami społecznymi, względnie oznaczają złamanie religijnego tabu; są to najczęściej zakazane związki miłosne;

3. skazanie bohatera na banicję, co stanowi najbardziej odpowiednią formę kary za jego występki;

4. dwa możliwe zakończenia historii wygnania:

1) cierpienie i śmierć bohatera na wygnaniu; pośmiertna deifikacja jako forma zadośćuczynienia;

2) powrót bohatera $\mathrm{w}$ blasku sławy do stolicy i osiągnięcie upragnionego sukcesu.

W rozważaniach literaturoznawczych często mówi się w tym kontekście o "schemacie narracyjnym podróży” (tabi no wakei). Shimauchi Keiji twierdzi, że podróż po pierwsze oznaczała pewien rodzaj wyobcowania, wykorzenienia, ciągłej wędrówki z miejsca na miejsce, a po drugie wpływała na dojrzewanie bohatera, wzbogacając jego osobowość i powodując, że wygnaniec stawał się człowiekiem wyjątkowym doświadczając wewnętrznej przemiany (Shimauchi 103).

Z kolei Małgorzata Czermińska, analizując XIX-wieczną literaturę polską, dostrzega uniwersalny charakter podróżowania, definiując to pojęcie jako „powtarzające się wątki wędrowne lub opowieści mityczne, mające status archaicznego prawzoru, powielanego następnie w niezliczonych modyfikacjach" (Czermińska 127). Jej zdaniem podróż można potraktować jako osobny rodzaj ludzkich zachowań. Czermińska wyróżnia kilka odmian podróży ze względu na cel jej odbywania. Obok podróży handlowej wymienia podróż dyplomatyczną, zdobywczą, naukową, dla rozrywki, pielgrzymkę, ucieczkę i właśnie wygnanie (Czermińska 129). W schemacie narracyjnym podróży dostrzega trzy etapy, a mianowicie akcję, którą stanowi sama podróż, przed-akcję będącą etapem przygotowań i po-akcję polegającą na pojawieniu się materialnych i duchowych owoców podróży (Czermińska 128). 
Podróż spowodowana wygnaniem jest zatem szczególnym typem podróżowania, ponieważ zgodnie $\mathrm{z}$ powyższym schematem przed-akcję stanowi czyn niezgodny z przyjętymi normami. Staje się on bezpośrednią przyczyną przemieszczania się. Po nim następuje akcja, czyli sam akt podróży wzbudzający różne przeżycia i dostarczający różnorodnych doświadczeń, i wreszcie jako trzeci etap pojawia się po-akcja będąca zapisem podróży i jej poszczególnych momentów.

Historia Ariwary doskonale wpisuje się w podstawowe założenia toposu „wygnania bohatera szlachetnie urodzonego" i schematu narracyjnego podróży. Ariwara wywodzi się bowiem z najwyższych warstw społecznych i jako potomek cesarza predestynowany jest do wyższych celów. Niestety w wyniku walki politycznej z potężnym już wówczas rodem Fujiwara ${ }^{14}$, zostaje skreślony z rejestrów rodu cesarskiego, a tym samym całkowicie odsunięty od władzy. W oczach prawa zostaje więc zwykłym dworzaninem, i kiedy wbrew woli Fujiwary Nagary nawiązuje romans z jego córką, księżniczką Takaiko, łamie w ten sposób wszelkie normy obowiązujące w społeczeństwie dworskim, stając się kochankiem kobiety, która została wybrana na przyszłą cesarzową. Kara wymierzona Ariwarze jest adekwatna do jego przestępstwa, nic bowiem nie mogło być w tym czasie bardziej upokarzającego i przytłaczającego jak nakaz opuszczenia stolicy. Ten etap wpisuje się w definicję przed-akcji, a po nim następuje akcja, czyli podróżowanie po prowincjach położonych na wschodzie Japonii, gdzie jakiś czas przyjdzie Ariwarze żyć z dala od świetności dworu cesarskiego. Etap po-akcji jest zapiskiem przeżyć Ariwary i przyjmuje formę lirycznych wyznań poety.

Warto dodać, że w Japonii topos „wygnania” po raz pierwszy pojawił się w Kojiki, czyli księdze dawnych wydarzeń, w której przedstawiona została historia Susanoo no mikoto, niepokornego brata bogini słońca Amaterasu (Kojiki, czyli księga dawnych wydarzeń 66-70). Susanoo złamał wszystkie możliwe tabu (grzechy niebiańskie i ziemskie) i został zesłany za swoje uczynki na ziemię. Topos wygania wykorzystany został również w Taketori monogatari (Opowieść o zbieraczu bambusów, X w.) i przez Murasaki Shikibu (X/XI w., lata życia nieznane) w Genji monogatari. Bohaterka Taketori monogatari księżniczka Kaguya, jako istota pochodząca z Księżyca zostaje zesłana na Ziemię, gdzie odbywa karę za swoje przewinienia (Taketori monogatari 97), natomiast tytułowy bohater powieści Murasaki, książę Genji zostaje skazany na wygnanie do Sumy z powodu występnego romansu z Oborozukiyo, konkubiną cesarza Suzaku, swojego przyrodniego brata (Genji monogatari 153-210).

Wędrówka Ariwary do prowincji wschodnich jest opisana w esejach siódmym, ósmym i dziewiątym. Ariwara wyruszył wraz z kilkoma towarzyszami w poszu-

14 Ród Fujiwara - jeden z najpotężniejszych rodów arystokratycznych, który w okresie Heian, dzięki umiejętnie prowadzonej polityce mariaży, zmonopolizował w swoich rękach realną władzę w Japonii. Przedstawiciele rodu, jako regenci i kanclerze, rządzili w imieniu cesarzy. 
kiwaniu miejsca do zamieszkania, ponieważ „ciężko mu było żyć w stolicy” (esej siódmy) (Ise monogatari 139). Przebył krainę Shinano, gdzie podziwiał wulkan Asama (esej ósmy), i następnie dotarł do prowincji Mikawa oraz Suruga, gdzie mógł zobaczyć piękną górę Fuji (esej dziewiąty).

A gdy zobaczyli górę Fuji, była ona pokryta bielutkim śniegiem, choć zbliżał się koniec miesiąca maja.

Szczyt góry Fuji nie zna pochodu czasu... $\quad$ O każdej porze jak na daniela skórze znajdziesz tam ptaty śniegu.

Jeśli porównać tę górę z podstołeczną górą Hiei, przewyższa ją ona chyba jakieś 20 razy, a wygląd jej przypomina pagórek z piasku morskiego, który po wyschnięciu zdaje się być obsypany solą. (Dziesięć tysięcy liści 141)

W eseju tym pojawia się słynny wiersz wychwalający górę Fuji i jej niezmienną, nieprzemijalną naturę (nie zna pochodu czasu/toki shiranu yama) (Dziesięć tysięcy liści 141). Jest to chyba jeden z niewielu w kulturze japońskiej symboli piękna, które ma wartość trwałą, niezmienną. Japończycy szczególnie upodobali sobie bowiem piękno przemijania, smutku i patosu (mono no aware lub aware).

W dziesiątym eseju Ariwara odwiedza pewną kobietę. Ojciec kobiety jest zwykłym człowiekiem, natomiast matka wywodzi się z potężnego rodu Fujiwara. Kiedy rodzina dowiaduje się o Ariwarze, następuje wymiana korespondencji.

[Ojciec] wysłał list do mężczyzny, którego chciał uczynić swoim zięciem. Mężczyzna mieszkał w okolicy Iruma, w wiosce Miyoshino.

Miyoshino no tanomu no kari mo hitaburu ni kimi ga kata ni zo yoru to nakunaru.

Dzika gąska przystanęła na skraju pola w Miyoshino. Na widok stracha na wróble zaczęła rzewnie tkać, jak moja córka, która ciebie pragnie.

W odpowiedzi otrzymał od mężczyzny list:

Waga kata ni yoru to nakunaru Miyoshino no tanomu no kari o itsuka wasuremu.

Twoja córka pragnie mojego wsparcia. Jakże mógłbym zapomnieć o siedzacej na polu, szlochajacej dzikiej gasce". (Ise monogatari 143)

Użyte $\mathrm{w}$ obu wierszach poetyckie słowo-homonim tanomu ma dwa znaczenia. Pierwsze związane jest $\mathrm{z}$ rzeczownikiem tanomu wskazującym na zewnętrzną część, obrzeże pola ryżowego, drugie natomiast pochodzi od czasownika tanomu „polegać na kimś”, „opierać się na kimś”. Wiersz ojca kobiety skierowany do Ariwary w sposób metaforyczny odzwierciedla jego pragnienie znalezienia dla córki odpowiedniego mężczyzny, które go mógłby obdarzyć zaufaniem. W drugiej części tego wiersza pojawia się inny poetycki homonim, a mianowicie hitaburu. Jego pierwsze znaczenie wywodzi się od zwrotu hita furu, czyli „deseczki wpra- 
wione w ruch przez wiatr", które rozwieszano na polach ryżowych w celu odstraszania ptaków. Drugie znaczenie ma natomiast związek z postacią koneksywną czasownika przymiotnikowego hitaburu nari - „całkowity", "zupełny", i wskazuje tutaj na potrzebę zaufania i całkowitego oparcia się na ukochanej osobie. Na uwagę zasługuje również rzeczownik kari, czyli dzika gęś, który stanowi eufemistyczny sposób określania młodej i pięknej kobiety.

W czternastym eseju Ariwara nawiązuje romans z kobietą z prowincji Michi. Przedstawiona historia miłosna jest dosyć zabawna, ale pokazuje $\mathrm{z}$ jednej strony kochliwość, a także wrażliwość Ariwary oraz jego empatyczną naturę, czyli najbardziej pożądaną cechę u mężczyzn określaną mianem irogonomi - „wysublimowanego pożądania"15.

Dawno temu pewien młodzieniec, podróżując bez specjalnego celu, przybył do krainy Michii ${ }^{16}$. Mieszkała tam kobieta, którą ów mężczyzna bardzo zainteresował.

- Jakiż przystojny i wspaniały musi być młodzieniec pochodzący ze stolicy - pomyślała kobieta i wysłała mu wiersz:

Nakanaka ni koi ni shinazu wa kuwako ni zo narubekarikeru tama no o bakari.

Czy warto umierać dla miłości? Już lepiej być jedwabnikiem, którego życie jest takie krótkie.

Jej wiersz był bardzo prowincjonalny [hinabi]. Mężczyzna kierowany głębokim współczuciem odwiedził kobietę, lecz opuścił jej dom, kiedy na dworze było jeszcze ciemno. Przed rozstaniem kobieta wyrecytowała:

Yo mo akeba kitsu ni hamenade kutakake no madaki ni nakite sena o yaritsuru.

Ten wstrętny kogut! Pragnętam utopić go o świcie w kadzi petnej wody,

lecz zapiał zbyt wcześnie i wygonit ukochanego.

Mężczyzna wyjaśnił, że zamierza wrócić do stolicy i na pożegnanie zostawił poemat:

Kurihara no anewa no matsu no hito naraba miya kono tsuto ni iza to iwamashi o

Gdyby sosna z Kurihary mogła być człowiekiem, zabratbym ją ze sobą na pamiatkę.

- Chyba powinnam z nim pojechać, on tak troszczy się o mnie - zachwycona jego słowami powiedziała sama do siebie. (Ise monogatari 146-147)

15 Pojęcie irogonomi wywodzące się od słów: iro - „kolor", ale też i „miłość”, „namiętność” oraz konomi - "upodobanie do", uwielbienie czegoś" używane było w kulturze dworskiej jako epitet określający ideał mężczyzny. Mężczyzna spełniający kryteria bycia irogonomi odznaczał się nieokiełznaną namiętnością i chęcią zawierania relacji miłosnych z różnymi kobietami, przy czym wyróżniał się empatią i wrażliwością.

${ }^{16}$ Kraj Michi oznacza północną część wyspy Honsiu i jest dawną nazwą regionu obejmującego dzisiaj kilka prowincji, między innymi: Ibaragi, Iwate, Miyagi oraz Fukushimę. 
Kobieta została przedstawiona jako osoba o niezwykle prowincjonalnym wychowaniu i wręcz prostackich manierach. Wbrew przyjętym obyczajom miłosnym sama przejawia inicjatywę i nawiązuje znajomość z mężczyzną wysyłając mu list. Jej poematy zaskakują prostotą i nieadekwatnością poetyckich metafor, szczególnie nieodpowiednie jest porównanie uczucia miłości do nietrwałego losu jedwabnika, który jako owad hodowlany nie był kojarzony z wyrafinowaną grą miłosną. Również reakcja kobiety na ostatni wiersz Ariwary świadczy o braku wyczucia i subtelności emocjonalnej. Sosna w kulturze dworskiej to symbol siły i trwałości, często oznaczała wspomnienie po zmarłej lub ukochanej osobie, nie mogła być natomiast pamiątką, którą można było zabrać ze sobą. Kobieta zupełnie niezrozumiała prawdziwych intencji mężczyzny i jego ironicznego stwierdzenia.

\section{Opowieść o kapłance ze świątyni Ise}

Kolejnym cyklem tematycznym uchodzącym za jeden z najważniejszych w Ise monogatari, jest romans Ariwary z kapłanką ze świątyni Ise. Spośród wszystkich opisanych w utworze historii miłosnych ta właśnie jest najbardziej wstrząsająca i zarazem wzruszająca. Przedstawiona została w kilku esejach: od sześćdziesiątego dziewiątego do siedemdziesiątego piątego oraz w esejach sto dwa i sto cztery.

We wczesnym okresie Heian dwór cesarski wysyłał na prowincję swoich posłańców, tzw. kari no tsukai (dosł. myśliwy), którzy zajmowali się nadzorem nad polowaniami i zaopatrywali dwór cesarski w dziczyznę serwowaną podczas różnych uroczystości dworskich ${ }^{17}$. W eseju sześćdziesiątym dziewiątym noszącym właśnie podtytuł Kari no tsukai, Ariwara udaje się do prowincji Ise w charakterze cesarskiego posłannika i nawiązuje romans z kapłanką świątyni zwaną Ise Saigū, Itsuki no miya lub Saiō. Kapłankami Ise zostawały najczęściej młode, niezamężne kobiety, które poświęcały się służbie bóstwom. Wywodziły się z najwyższych warstw społecznych, a więc z rodzin książęcych lub rodu cesarskiego. Ich służba rozpoczynała się $\mathrm{w}$ dniu intronizacja i kończyła $\mathrm{w}$ dniu detronizacja danego cesarza ${ }^{18}$. Kapłanki musiały przestrzegać ślubów czystości i oprócz cesarza nie wolno im było mieć kontaktów seksualnych z innymi mężczyznami. W powyższym eseju księżniczka Yasuko, córka cesarza Montoku (827-858, panował 850-858) i siostra księcia Koretaki (844-897), która została kapłanką Ise, potajemnie spotyka się z Ariwarą.

17 Posłaniec kari no tsukai najczęściej posiadał czwartą lub piątą rangę dworską i pełnił funkcję kurōdo, czyli szambelana. W okresie Heian funkcjonował system rang i przypisanych im urzędów dworskich. Wprowadzono cztery rangi książęce i dziewięć rang dworskich, które były dodatkowo dzielone na dwa stopnie. Czwarta i piąta ranga dworska należały do średnich w hierarchii rang.

18 System, który wprowadzono prawdopodobnie za czasów legendarnego cesarza Sujina, przetrwał do czasów cesarza Godaigo (1288-1339, panował 1318-1339). 
Do pierwszego spotkania doszło na prośbę matki Yasuko, która poleciła córce godnie ugościć wysłannika cesarza. Kapłanka spełniła wolę matki i „nad ranem, kiedy [Ariwara] udawał się na polowanie, przyszła go odprowadzić, wieczorem zaś, kiedy wrócił, zaprosiła go do swojej komnaty mieszczącej się na terenie świątyni" (Ise monogatari 191). Znajomość bardzo szybko przerodziła się w głębsze uczucie. Już następnej nocy mężczyzna postanowił spotkać się z kobietą, ale nie mógł udać się do świątyni na noc nie narażając się na wykrycie, dlatego tym razem kapłanka odwiedziła Ariwarę późną nocą w jego komnatę.

Mężczyzna pogrążony w myślach o ukochanej, nie mógł zasnąć. Leżąc spoglądał przez okno. W delikatnym świetle księżyca ujrzał najpierw młodą służącą, a tuż za nią dostrzegł stojącą kobietę. Mężczyzna, niezmiernie rozradowany, zaprowadził ukochaną do swojego łoża. Spędzili miło czas od godziny pierwszej do trzeciej w nocy. I zanim się zorientował, kobieta opuściła jego dom. Mężczyzna poczuł się zrozpaczony, i już do rana nie mógł zasnąć. Następnego poranka z niecierpliwością oczekiwał na jakąś wiadomość od ukochanej, kiedy jednak posłaniec nie przybył, wieczorem sam wysłał jej poemat:

Kimi ya koshi ware ya yukikemu omōezu yume ka utsutsu ka nete ka samete ka.

Nie wiem, czy ty przyszłaś do mnie, czy to ja poszedtem do ciebie? Czy to byt sen czy jawa? Czy tylko drzemałem, a może już nie spałem?

I kolejny wiersz, który napisał, wzbudził w nim uczucie rozpaczy:

Kakikurasu kokoro no yami ni madoiniki yume utsutsu to wa koyoi sadameyo.

Moje serce btadzi w zamęcie mroku. Może dziś wieczorem uda nam się rozstrzygnać czy wszystko było tylko snem, czy może jednak jawa. (Ise monogatari 191-192)

Następnego dnia mężczyzna udał się na polowanie, niestety po powrocie nie mógł spotkać się z ukochaną, ponieważ musiał spędzić wieczór z posłańcem cesarskim.

W kolejnych esejach: siedemdziesiątym, siedemdziesiątym pierwszym i drugim wątek romansu z kapłanką Ise zostaje rozwinięty. Ariwara odczuwa żal na myśl, że okoliczności zewnętrzne uniemożliwiają im ponowne spotkanie, koresponduje jednak z ukochaną (eseje siedemdziesiąty pierwszy i drugi) lub z jej służącą (esej siedemdziesiąty) nieustannie. W jednym z listów pisze do ukochanej:

Koishiku wa kite mo miyo kashi chiwayaburu kami no isamuru michi nara naku ni.

Tęsknisz za mną? Jeśli tak, przyjdź do mnie! To nie jest przecież droga, która bogowie zabraniaja kroczyć. (Ise monogatari 194)

W innym wierszu z kolei, zachęcając kobietę do spotkania, wyznaje jej:

Me ni wa mite te ni wa torarenu tsuki no uchi no katsura no gotoki kimi ni zo arikeru.

Niedostępne drzewo katsura na tle księżycowej poświaty. Moge jedynie je podziwiać. Tak bardzo przypomina mi Ciebie. (Ise monogatari 195) 
Ariwara przyrównuje ukochaną na drzewa katsura (łac. Cercidiphyllum), które według chińskiej legendy porasta księżycowe pola. Tutaj katsura jest symbolem pięknej i niedostępnej kobiety, którą można jedynie podziwiać, ale nie można jej zdobyć (te wa ni toranu).

Ariwara już nigdy więcej nie spotkał się z kapłanką Ise, pozostała mu jedynie wymiana korespondencji.

\section{Podsumowanie}

Podsumowując powyższe rozważania na temat Ise monogatari, należy podkreślić, iż z wielu punktów widzenia jest to dzieło nowatorskie i oryginalne. Można je rozpatrywać na dwóch poziomach semantycznych. Pierwszy wynika z perspektywy społecznej, drugi natomiast - z literackiej. Perspektywa społeczna umożliwia rozpoznanie dzieła jako pewnego rodzaju manifestu politycznego kreującego Ariwarę na bohatera tragicznego odsuniętego od wpływów na dworze cesarskim i władzy. Ariwara stara się zawsze postępować zgodnie ze swoimi uczuciami, dlatego nie boi się łamać zasad i narazić na karę. Staje się w ten sposób symbolem protestu przeciw wpływom potężnego już wówczas rodu Fujiwara. Jednocześnie to właśnie on wyznacza normy eleganckiego zachowania (miyabi) i emocjonalnej wrażliwości (irogonomi). Uczuciowość i wrażliwość poety stanowią zarazem formę jego walki z potężnym przeciwnikiem, którego politycznie nie jest w stanie pokonać. W tym kontekście Ise monogatari staje się manifestem kultury miyabi.

Druga perspektywa ma charakter literacki, bowiem Ise monogatari stanowi pierwszy i zarazem najwybitniejszy przykład gatunku uta monogatari będącego połączeniem liryki i epiki narracyjnej. Partie epickie stanowią warstwę drugoplanową wobec partii lirycznych, które przybierają formę korespondencji lub aktów wyznania. Liryczny obraz życia głównego bohatera ma wymiar psychologiczny, ukazuje bowiem jego proces dojrzewania i buntu przeciw zastanym normom.

\section{BIBLIOGRAFIA}

Bowring, Richard. The Ise monogatari: A Short Cultural History, Harvard Journal of Asiatic Studies 12 (1992). S. 401-480.

Cranston, Edwin A. The Dark Path: Images of Longing in Japanese Love Poetry, Harvard Journal of Asiatic Studies 35 (1975). S. 60-100.

Czermińska, Małgorzata. „Podróż jako budowanie tożsamości. Rekonstrukcja narracji niekompletnych". Narracja i tożsamość II, antropologiczne problemy literatury. Red. Włodzimierz Bolecki, Ryszard Nycz. Warszawa: IBL, 2004.

Dziesięć tysięcy liści. Przeł. Wiesław Kotański. Warszawa: PWN, 2012.

Fukui, Teisuke. „Ise monogatari” (Opowieści z Ise). Nihon koten bungaku zenshū (Zbiór wszystkich dzieł klasycznej literatury japońskiej), T. 8. Tōkyō: Shōgakukan, 1972. S. 113-128. 
Hara, Kunito. Ise monogatari bungeishiteki kenkyū (Studia na temat historii badań literackich nad Opowieściami z Ise). Tōkyō: Shintensha Kenkyū Saisho, 2001.

Hara, Kunito. Ise monogatari no genpūkei no yukue o tazunete (Pierwotny krajobraz Opowieści z Ise, w poszukiwaniu miłości). Tōkyō: Yūseidō, 1985.

Hinata, Kazumasa. „Uta monogatari no tenkai” (Rozwój opowieści do pieśni). Nihon bungeishi, kodai (Historia literatury japońskiej, starożytność). T. 2. Tōkyō: Kawade Shobō, 1986. S. 103-117.

Ikeda, Kikan. Ise monogatari ni tsuite no kenkyū (O badaniach na temat Opowieści z Ise). Tōkyō: Ōzakisan Shoten, 1960.

Katagiri, Yōichi. Ise monogatrai no kenkyū, kenkyūhen (Badania na temat Opowieści z Ise, tom badawczy). Tōkyō: Meiji Shoin, 1968.

Katagiri, Yōichi. Ise monogatrai no kenkyū, shiryōhen (Badania na temat Opowieści z Ise, tom źródeł badawczych). Tōkyō: Meiji Shoin, 1969.

Ki no, Tsurayuki. „Kanajo” (Wprowadzenie). Kokinwakashū (Zbiór pieśni dawnych i dzisiejszych). Tōkyō: Kadokawa Bunko, 1989.

Ki no, Yoshimochi. „Manajo” (Wprowadzenie). Kokinwakashû (Zbiór pieśni dawnych i dzisiejszych). Tōkyō: Kadokawa Bunko, 1989.

Kojiki, czyli księga dawnych wydarzeń. Przekł. Wiesław Kotański. Warszawa: PIW, 1986.

Kuboki, Tetsuo. „Ise monogatari no uta, ke no uta ni kansuru ikkōsatsu” (Poematy z Opowieści z Ise, rozważania na temat liryki osobistej). Ise monogatari to Utsuho monogatari (Opowieści z Ise i Opowieści z dziupli). Kokubungaku 2 (1998). S. 32-38.

Marra, Michele. The Aesthetics of Discontent, Politics and Reclusion in Medieval Japanese Literature. Honolulu: University of Hawaii Press, 1991. S. 35-54.

Mitani, Kuniaki. Ōken no monogatari kōzō, ōken e no okashi aruiwa kishu ryūritan to irogonomi (Struktura dworskich opowieści, wykroczenie wobec władzy cesarskiej lub motyw wygnania a irogonomi/wysublimowane pożądanie). Kokubungaku 10 (1999). S. 34-41.

Mostow, Joshua S. "Modern Construction of Tales of Ise: Gender and Courtliness". Inventing the Classics, Modernity, National Identity and Japanese Literature. California: Stanford Univeristy Press, 2000. S. 96-120.

Nihongo gogen jiten (Słownik etymologiczny języka japońskiego). Słownik elektroniczny Casio, 2004

Murasaki, Shikibu. Genji monogatari (Opowieść o księciu Genjim). T.11-15. Tōkyō: Shōgakukan, 1972.

Ōchō monogatari no hikkei (Wprowadzenie do opowieści dworskich). Red. Fujii, Sadakazu. Bessatsu kokubungaku (1987).

Sagoromo monogatari (Opowieść o Sagoromo). Tōkyō: Iwanami Shoten, 1975.

Taketori monogatari (Opowieść o zbieraczu bambusów), T. 8. Tōkyō: Shōgakukan, 1972.

Waka no kaishaku to kanshō jiten (Słownik interpretacji i rozumienia poezji japońskiej waka). Red. Inoue M., Mukawa Ch. Tōkyō: Kasama Shoin, 1999.

Watanabe, Hideo. „Koten kaishaku ni okeru kindai to zenkindai, Kokinwakashūjo no „waka hasseiron” no rikai o megutte" (Nowożytność i prenowożytność w interpretacji literatury klasycznej. Wstęp do Kokinshū a teoria rozwoju poezji waka). Analecta Nipponica 2 (2012). S. 11-20.

Yamada, Seiichi. Ise monogatari no seiritsu to denpon no kenkyū (Badania na temat powstania i wersji odpisu Opowieści z Ise). Tōkyō: Sakurafūsha, 1972.

Yamato monogatari (Opowieści z Yamato). T. 8. Tōkyō: Shōgakukan, 1972.

Yanagita, Tadanori. „Mukashi otoko no seisei, Kokinshū Ariwara uta o kaishite” (Narodziny dawnego mężczyzny, na podstawie poematów Ariwary zamieszczonych w Kokinshū). Ise monogatari to Utsuho monogatari (Opowieści z Ise i Opowieści z dziupli). Kokubungaku 2 (1998). 